\title{
Thermal behavior, Chemical, Mineralogical and Optical Characterization of clays (Kaolin) for industrial use as refractory material
}

\author{
R. Moreno-Tovar ${ }^{a}$, F. Pérez-Moreno ${ }^{b}, A$. Arenas-Flores ${ }^{c}$ \\ and L. M. Romero-Guerrero ${ }^{d}$
}

Universidad Autónoma del Estado de Hidalgo. Instituto de Ciencias Básicas e Ingeniería. Carr. Pachuca Tulancingo Km 4.5, C.P. 42186. Col. Carboneras. Mpio. Mineral de la Reforma, Hidalgo, México.

amorenot@uaeh.reduaeh.mx, bfpmoreno2003@hotmail.com, careshef2001@hotmail.com, and ${ }^{\mathrm{d}}$ mikel_1782@hotmail.com

Keywords: Characterization, clays, thermal behavior, chemical, mineralogical, refractory material

\begin{abstract}
The kaolin is an important component of a wide variety of industrial products, therefore kaolin samples of region mines Huayacocotla, Veracruz and Alumbres, Hidalgo were collected, these were treated to reduce the size particle employment an agate mortar and part of each one were analyzed using analytical techniques such as: absorption and emission atomic spectroscopy (AEAS), optical microscopy of polarization (OMP); X-rays diffraction (XRD); refractory test under ASTM standard C-24-79 using a pyrometric cone mold designed on ASTM standard C-24 and thermal test at different temperatures up to $1600{ }^{\circ} \mathrm{C}$ with heating and cooling rate of $2.5^{\circ} \mathrm{C} \cdot \mathrm{min}^{-1}$. Dates from elemental analysis were converted to percentage in oxides form of major elements. The analysis by OMP showed kaolin alteration degree in the region due to minerals such: plagioclase, feldspar and quartz, hydrothermal alteration of epithermal type represented by oxidation, sulfides (pyrite, galena) and association with chlorite. X-ray diffraction allowed determining kaolinite $\left(\mathrm{Al}_{2} \mathrm{O}_{3} \cdot 2 \mathrm{SiO}_{2} \cdot 2 \mathrm{H}_{2} \mathrm{O}\right)$ as majority phase in both Huayacocotla and Alumbres; Cristobalite $\left(\mathrm{SiO}_{2}\right)$ and Mullite $\left(3 \mathrm{Al}_{2} \mathrm{O}_{3} \cdot 2 \mathrm{SiO}_{2}\right)$ were observed in both samples at high temperatures. Kaolin softening point was determined in $1300-1600{ }^{\circ} \mathrm{C}$ range, and it makes it feasible as refractory material of low and high temperature. Thermo gravimetric analysis showed that Huayacocotla kaolin are most stable than Alumbres.
\end{abstract}

\section{Introduction}

The clay term is used to designate a minerals group, specifically hydrophilic aluminum phyllosilicates present in colloidal matter and pieces of rock fragments, this material becomes plastic when it hydrates and stone by heat action. According to composition, nature and physical properties, the use and clay value are determined [1,2]. The presence of crystalline quartz reduces its plasticity, shrinkage and also contributes to make refractory, silica in colloidal form increases its plasticity and aluminum oxide makes refractory. The presences of $\mathrm{Fe}, \mathrm{Na}$, and $\mathrm{K}$ as oxides decrease the melting temperature and also act as fusing; iron oxides act as powerful coloring agents [3]. Refractory clays generally have high percentage of kaolinite with some free quartz as impurity and have a value equal to 18 from pyrometric cone $\left(1508^{\circ} \mathrm{C}\right)$ or higher [4].

Kaolin is still a preferred row material for ceramics due to interesting characteristics as porous ceramics [5], several kaolinites clays have been improved to prepare porous Mullite based ceramics $[6,7]$. The main raw materials are: Kaolin, feldspar and quartz, and taking into account the attractive properties of Kaolin, several devices are generally manufactured from compounds such as Alumina $\left(\mathrm{Al}_{2} \mathrm{O}_{3}\right)$, Mullite $\left(3 \mathrm{Al}_{2} \mathrm{O}_{3} \cdot 2 \mathrm{SiO}_{2}\right)$ and Cordierite $\left(2 \mathrm{MgO} \cdot 2 \mathrm{Al}_{2} \mathrm{O}_{3} \cdot 5 \mathrm{SiO}_{2}\right)$ which are relatively expensive [8]. Due that there are many kaolin deposits in Hidalgo's state with interesting alumina and silica contents and the interest to prepare alternating materials base kaolin as refractory materials of low cost has grown rapidly. The kaolin must have relatively low iron and titanium content to have good refractory properties. 


\section{Experimental work}

Sample preparation. Kaolin samples from Huayacocotla, Veracruz and Alumbres, Hidalgo mining region were carrying out based on physical differences of color, texture and particle size, among others; kaolin particle size were reduced to less than $100 \mu \mathrm{m}$ with agate mortar previous this material were characterized.

Elemental analysis. $0.4 \mathrm{~g}$ of sample was settled in a digester beaker of high density polypropylene with $11 \mathrm{~mL}$ of mixture $\mathrm{HCl}, \mathrm{HNO}_{3}$ and $\mathrm{HF}(3: 1: 7)$ concentrated and were digested in microwave oven (CEM, Mar SX model), the samples were heated from ambient temperature up to $200{ }^{\circ} \mathrm{C}$ in $25 \mathrm{~min}$ and holding this temperature for $15 \mathrm{~min}$; the samples were left to cool and then 35 $\mathrm{ml}$ of $\mathrm{H}_{3} \mathrm{BO}_{3}$ were added to each one digester beaker and held a second digestion up to $200{ }^{\circ} \mathrm{C}$ in 15 min [9], and the elemental analysis was carried out with an inductive coupled plasma spectrophotometer (ICP) Perkin Elmer, 3000 XL model and a certified multielemental standard was used for quantification; the concentration determined in the samples became in percentages of their respective oxides.

Optical and XRD characterization. For optical characterization, the sample was treated and placed in an optical microscope of polarization and was used the Entellan technique. $1.0 \mathrm{~g}$ of powder sample mesh 200 was placed in a rotary port samples of lainamil on a XRD (Inel, Equinox 2000) equipped with simultaneous detector curved which uses a mixture of ethane-argon of high purity with a power source of $15 \mathrm{Kv}$ A, which operates to $20 \mathrm{~mA}$ and $30 \mathrm{Kv}$ with cathode of $\mathrm{Cu}$ and $\mathrm{K}_{\alpha}=1.54 \AA$; the analysis was performed by a scanned of $60 \mathrm{~min}$ and data processing was carried out with Match Software and Jade 6 (Inel/Materials Data, Inc).

Pyrometric cone. For refractory tests were used $5 \mathrm{~g}$ samples mixed with gum Arabic as organic binder to form a paste which were placed inside moulds for pyrometric cone and these were compacted in a homogeneous way, the samples were left to dry for $5 \mathrm{~min}$ before demolding, the cones were placed along with a witness cone on a refractory base; these were placed in a heating furnace (Nabertherm) flask type and these were heated from ambient temperature up to $1600{ }^{\circ} \mathrm{C}$ with heating and cooling rate of $2.5^{\circ} \mathrm{C} \mathrm{min}$.

TGA characterization. Finally, $3.0 \mathrm{mg}$ samples of each one finely pulverized were placed in alumina crucibles of $40 \mu \mathrm{l}$ capacity and placed into a thermo gravimetric equipment (Mettler, TGA/SDTA 851e) previously calibrated with In and $\mathrm{Al}$ and a heating dynamic program was used to raise the temperature of the oven from $35^{\circ} \mathrm{C}$ up to $1000{ }^{\circ} \mathrm{C}$ with heating rate of $10{ }^{\circ} \mathrm{C} \mathrm{min}{ }^{-1}$ using Star program $9.2 \mathrm{v}$.

\section{Results and discussion}

Dates obtained from elemental analysis were become to oxides percentage and it is observed that Alumbres kaolin has slightly higher content of $\mathrm{SiO}_{2}, \mathrm{TiO}_{2}, \mathrm{~K}_{2} \mathrm{O}$ and $\mathrm{FeO}$ than Huayacocotla samples, while $\mathrm{CaO}, \mathrm{Na}_{2} \mathrm{O}$ are higher in Huayacocotla (Table 1); the $\mathrm{FeO}$ content act as fluxing that decrease the melting point of the materials.

Table 1. Kaolin composition from Huayacocotla, Veracruz and Alumbres, Hidalgo, Mex.

\begin{tabular}{|c|c|c|}
\hline Oxides & $\begin{array}{c}\text { Huayacocotla } \\
\text { Zone (\%) }\end{array}$ & $\begin{array}{c}\text { Alumbres } \\
\text { Zone (\%) }\end{array}$ \\
\hline $\mathrm{SiO}_{2}$ & 65.127 & 68.155 \\
\hline $\mathrm{Al}_{2} \mathrm{O}_{3}$ & 18.600 & 18.271 \\
\hline $\mathrm{CaO}$ & 0.160 & 0.015 \\
\hline $\mathrm{K} 2 \mathrm{O}$ & 0.599 & 0.706 \\
\hline $\mathrm{MnO}$ & 0.005 & 0.006 \\
\hline $\mathrm{FeO}$ & 0.339 & 2.721 \\
\hline $\mathrm{Na}_{2} \mathrm{O}$ & 0.477 & 0.194 \\
\hline $\mathrm{TiO}_{2}$ & 0.397 & 0.414 \\
\hline
\end{tabular}


The kaolins studied by XRD without heat treatment to 200 meshes shown presence of kaolinite as main phase and Cristobalite as secondary phase in Huayacocotla, Veracruz and Alumbres, Hidalgo samples. The heat treatment was carried out up to $1600{ }^{\circ} \mathrm{C}$ several transformations take place at temperatures above $1350{ }^{\circ} \mathrm{C}$ and the presence of Mullite and Cristobalite were detected in samples; when temperature increases the intensity of the sign of Cristobalite phase decrease and Mullite phase increase (Fig. 1).

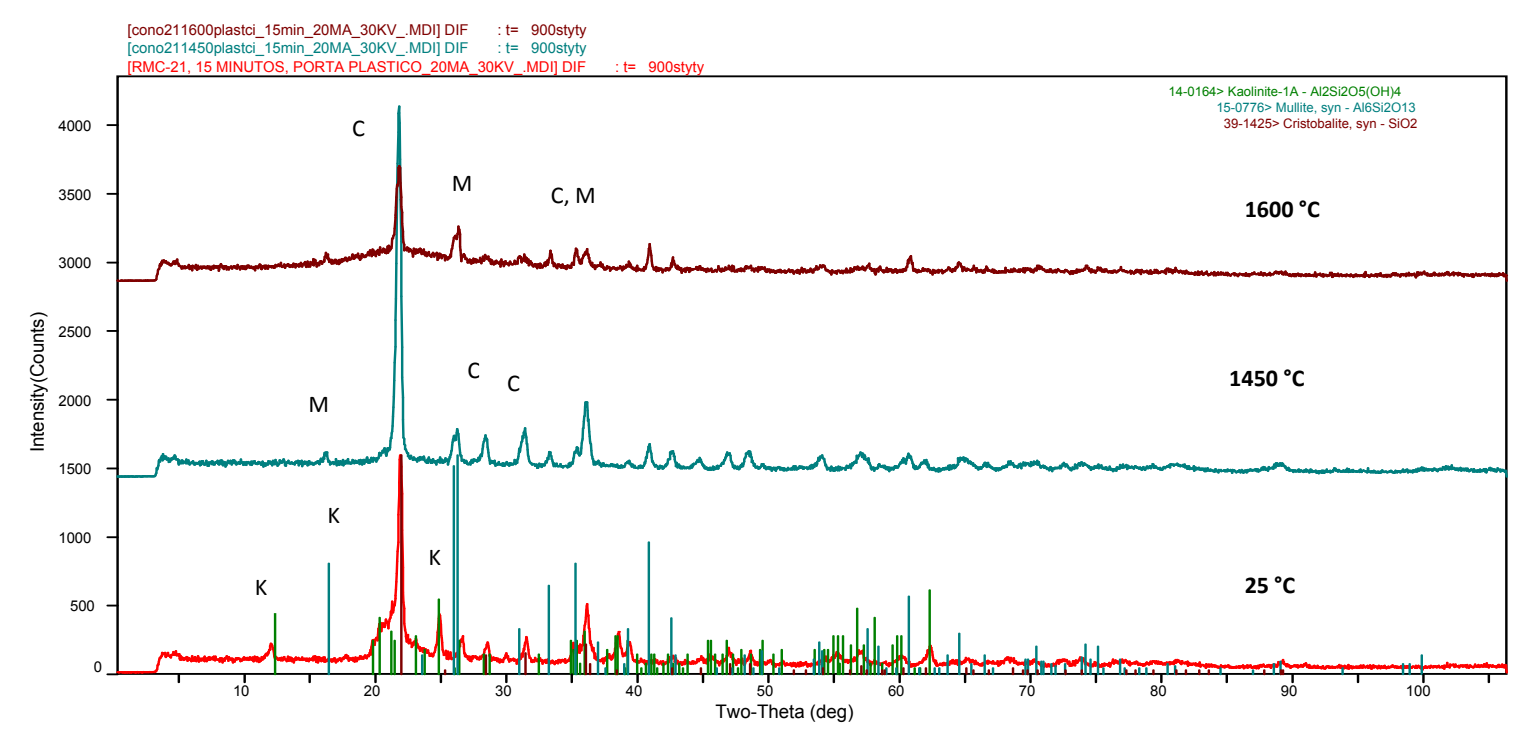

Fig. 1. XRD Patterns of kaolin from Huayacocotla, Veracruz. Working conditions: XRD equipment (Inel, Equinox 2000); $2 \theta$ angle from $5^{\circ}$ to $105^{\circ}$ to $30 \mathrm{kv}$ and $20 \mathrm{~mA}$. Cristobalite (C), Kaolinite (K) and Mullite (M).

OMP analysis shown the kaolinization degree, since Huayacocotla samples present abundant clays with weak acicular crystal habit associated with opaque minerals in high relief (Fig. 2a); Alumbres samples have a clayey ground strongly oxidized with strong development of metal ore (pyrite) of cubic crystal system (Fig. 2b).
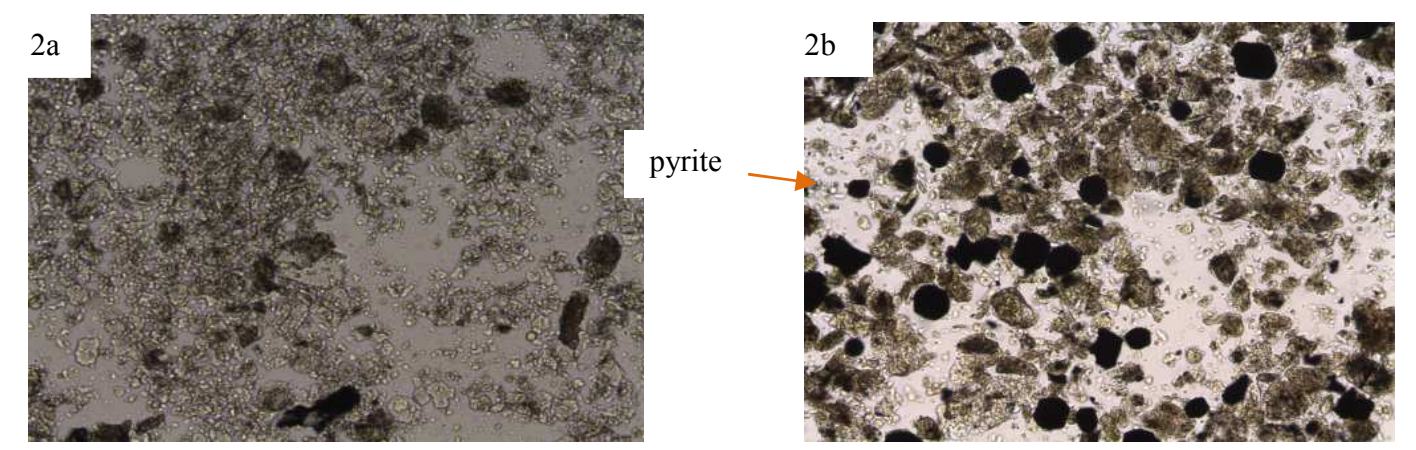

Fig. 2. OMP analysis of kaolin from Huayacocotla, Veracruz present weak acicular crystals habit associated with opaque minerals in high relief (a) and Alumbres, Hidalgo illustrate development of pyrite as cubic crystal system (b).

During kaolin heat treatment of undergoes a series of transformation can be seen from figure 3, the water disposal which occurs from 120 to $300{ }^{\circ} \mathrm{C}$ onwards, it is a very endothermic phenomenon; the amorphous metakaolin, $\mathrm{Al}_{2} \mathrm{O}_{3}\left(\mathrm{SiO}_{2}\right)_{2}$ formed exhibits a structural organization directly derived from kaolinite. The exothermic transformation observed between 420 and $520{ }^{\circ} \mathrm{C}$ is a structural reorganization of amorphous metakaolin, sometimes associated with Mullite phase formation 
$\mathrm{Al}_{2.34} \mathrm{Si}_{0.66} \mathrm{O}_{4.83}$ [10]; between 1000 and $1100{ }^{\circ} \mathrm{C}$ (often around $1075{ }^{\circ} \mathrm{C}$ ), these phases are transformed to Mullite and Cristobalite during this reaction the amorphous silica is released and surplus amorphous silica starts to crystallize in Cristobalite form from $1200{ }^{\circ} \mathrm{C}$ onwards.

The refractoriness test made from $450{ }^{\circ} \mathrm{C}-1600{ }^{\circ} \mathrm{C}$ show softening temperature due to effect of $\mathrm{Na}_{2} \mathrm{O}$ and $\mathrm{K}_{2} \mathrm{O}$, which reduce the refractoriness since they act as fluxes, i.e., reduce the liquidus kaolin temperature and the sodium can reduce the melting temperature from $1720{ }^{\circ} \mathrm{C}$ to $800{ }^{\circ} \mathrm{C}$ in the eutectic composition [11]. High content of fluxes increases vitria phase and crystallinity decreases, reducing its refractoriness.

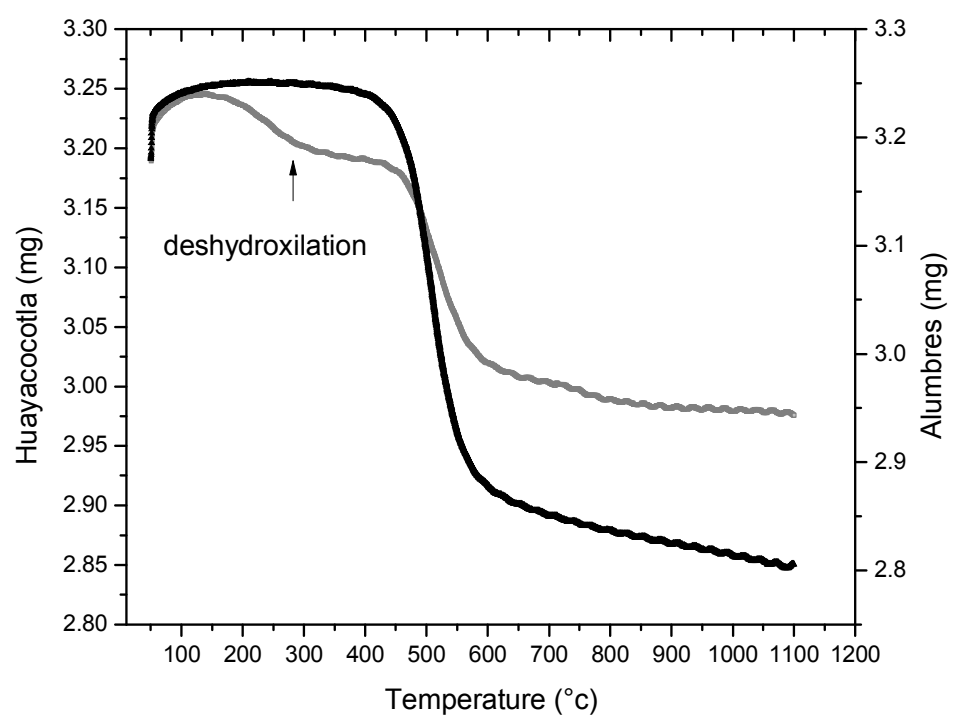

Fig. 3. TGA analysis of kaolin from Huayacocotla, Veracruz. and Alumbres, Hidalgo. Huayacocotla (black line) sample present deshydroxilation from 120 to $300{ }^{\circ} \mathrm{C}$ and is more stable than Alumbres (grey line).

\section{Conclusions}

According elemental analysis, the main oxides of kaolin are alumina and silica which were confirmed by XRD qualitative analysis, Mullite and Cristobalite phases were observed at high temperatures.

TGA studies clearly demonstrates that Huayacocotla kaolin is most stable than Alumbres which is indicated by its short slope.

Huayacocotla kaolin can be used as a refractory material due to a high refractoriness, low fluxes content and iron oxides.

\section{Acknowledgements}

The authors acknowledge the support from SEP, CONACyT, and UAEH to develop the present work. 


\section{References}

[1] A. Zoltán and R. B. Williams: World Health Organization (2005), p.177

[2] S. B. Badmus and B. O. Olatinsu: International Journal of Physical Sciences Vol 4 (2009), p. 592

[3] P. A. Scroeder, R. J. Pruett and N. D. Melear: Clays and Clay Minerals Vol 52 (2004), p. 211

[4] O. Folorunso, P. A. Olubambi and O. J. Borode: Leonardo Electronic Journal of Practices and Technologies (2012), p. 25

[5] L. Ganesh and J. M. F. Ferreira: Ceramics International Vol. 35 (2009), p. 2007

[6] I. F. Liux, X. Q. Liu, H. Wei and G. Y. Meng: Ceramics International Vol 27 (2001), p. 1

[7] J. Bai: Ceramics International Vol. 36 (2010), p. 673

[8] H. Harabi, F. Zenikheri, B. Boundaria, F. Bouzerara, A. Guechia and L. Foughali: Journal of European Ceramic Society Vol. 34 (2014), p. 1329

[9] J. C. Warren, B. Xing and J. M. Dudas: Canadian Journal of Soil Science Vol 70 (1990), p. 617

[10] D. R. Treadwell, D. M. Dabbs and I. A. Aksay: Chemistry of Materials Vol 8 (1996), p. 2056

[11] A. F. Arenas: Refractariedad de las ignimbritas o canteras del municipio de Morelia, Michoacán, México. Master's thesis. Instituto de Investigaciones Metalúrgicas. Universidad Michoacana de San Nicolás de Hidalgo (1996). 